\title{
From the Challenges Imposed by Climate Change to the Preservation of Ecosystem Processes and Services
}

\author{
Rita Anastácio*, Mário Jorge Pereira \\ Departamento de Biologia e CESAM, Universidade de Aveiro, Aveiro, Portugal \\ Email: *rita_sofia@msn.com
}

How to cite this paper: Anastácio, R. and Pereira, M.J. (2017) From the Challenges Imposed by Climate Change to the Preservation of Ecosystem Processes and Services. Natural Resources, 8, 788-807. https://doi.org/10.4236/nr.2017.812048

Received: November 20, 2017

Accepted: December 26, 2017

Published: December 29, 2017

Copyright (c) 2017 by authors and Scientific Research Publishing Inc. This work is licensed under the Creative Commons Attribution International License (CC BY 4.0).

http://creativecommons.org/licenses/by/4.0/

\section{cc) (i) Open Access}

\begin{abstract}
Today, especially in countries that offer a satisfactory quality of life, it is easy to forget that we depend directly and indirectly on services provided by ecosystems such as quantity and quality of water, energy, food, health, and shelter. In less developed countries, the daily struggle for essential goods makes this dependency more real, despite the lack of knowledge, organization and/or financial resources to deal with the problems imposed on ecosystems by climate and anthropogenic changes. Protecting ecosystems by ensuring the services they provide has become highly dependent on our management capacity, our understanding of its functioning, and our capacity for persuasion. Demographic pressure and individualism compromise the survival of various species, including our own, and create pressures under governments and the stability of nations. The notion of facing a global challenge has awakened in the scientific community the need to focus on developing global strategies that change the mind-sets of decision makers, industry, governments and markets. Global knowledge networks and experts are being built to mitigate problems on a global scale. In this mini review, the authors make a brief visit to documents, intergovernmental initiatives, and platforms that have been built with the aim of contributing to promote a resolution for the global problems.
\end{abstract}

\section{Keywords}

Roads to Dignity, Essential Biodiversity Variables, Kyoto Protocol, IPCC, Ecosystem Services Profile, SDG's

\section{Introduction}

Climate changes open new challenges to the ecosystem services, freely offered by nature but, usually, not perceived by people [1]. We all rely, directly or indirect- 
ly, on those services (e.g. water, energy, food, health, shelter), especially the poorest, in particular from less developed countries from Africa, South America and Asia [2] [3] [4]. Climate changes have opened the opportunity for species to explore new geographies, in land and sea, without the help of humans as carriers. These species are exploring new locations and are imposing a new equilibrium, changing services from which local populations are dependent.

Protecting ecosystems and ensuring their natural services, based on advised management, is crucial in order to maintain and improve the quality of life. The demographic pressure and the absence of what each person needs and perceives is compromising our survival, and creates an enormous pressure on governments. In this extreme scenario, for local/regional populations the capability to survive is put at risk.

The movie "After Earth" is an example of how Earth and its nature can evolve into something without humans. People think it is possible to control everything in the world, but this is not the truth. The planet is resilient, and its life forms are also resilient, though mutable. A species can evolve or become extinct. Our species obeys to this axiom. So, we cannot control our environment forever. We can, however, use our advanced technology and knowledge to mitigate problems we face: our exponential growth, our demand for natural resources, diseases, among others. And, we may solve problems we created like pollution and climate change-like the measure of banning the use of CFCs and the recovery of the ozone layer [5] - knowing that they are too challenging, too big, and too global to deal with. We are alone as a species to solve problems, and we face the complexity of not being together to achieve the goals that may reduce our difficulties.

The Social and Exact Sciences play a crucial role. It is because the scientific community is aware of the current and future challenges, which they have begun to focus in developing global strategies to change the mentality of governors, policy makers and important stakeholders in the industry and economics. Global entities preoccupied with climate change and pressures suffered by poor countries related with lack of resources flourished in the last decades and are trying to make a change.

In this review something became very clear: people are building global effective nets of expertise to mitigate global challenging and demanding problems. Biodiversity loss, famine (due to low agriculture yields, marine resources depletion), lack of fresh water and demand for areas to explore are some of them. Perhaps natural and intellectual resources need to be managed in a more global way, since there are so many disparities in the distribution of them. Roads to Dignity by 2030 [6] proposes (at the $125^{\text {th }}$ topic) "to establish an online, global platform, building on and complementing existing initiatives, with the participation of all relevant stakeholders (...)".

Sachs et al. [7] [8] advocate a global network to supervise agriculture; Scholes et al. [9] and Pereira et al. [10] advocate also an "Essential Biodiversity Variables" (EBVs) 
discussion for the GEOBON (https://www.geobon.org) project (and other similar projects); there is already a Global Climate Observing System (GCOS-WMO https://public.wmo.int/en/programmes/global-climate-observing-system) that defined "Essential Climate Variables" (ECV), and more global networks will be needed, since global strategies work like emphasized by the IPCC [11].

Rands et al. [12] proposed the establishment of an Intergovernmental SciencePolicy Platform on Biodiversity and Ecosystem Services, which would help (they advocated) to close knowledge gaps (about status, trends, functional importance of microorganisms, many plant groups and even vertebrates, about genetic diversity and how different components of biodiversity contribute and relate to the provision of services or create resilience to environmental change) "and link science and economics to the policy step-change needed to conserve biodiversity". These steps are called the "three tiers to halt biodiversity loss". Jumping directly to the instrumental tier (Legislation, giving markets incentives and develop technolo$g y$ ) is not recommended without ensuring the enabling tier (work with institutions and governance in order to develop awareness to change behavioural patterns in the society, through educational campaigns at schools and media, for example) [12].

Paetzold et al. [13] also advocated an Ecosystem Services Profile (EPS) framework-combined with cyclic assessments and management frameworks-to make ecosystem assessments to evaluate the status of its characteristics and services (e.g. assessing ecological quality) to provide information for decision and policy makers for an "adaptive management approach" of those ecosystems; de Groot et al. [14] also emphasizes that a "coherent and integrated approach" for ecosystem and landscape functions planning, management and decision-making similar to what the ARIES-project is doing for Conservation International is challenging but necessary.

As a species, our strategy of uniting efforts is, perhaps, our only way to overcome our extinction. Nevertheless, SOTW's following statement gives a warning "Humanity's ability to marshal the earth's resources, along with the economic and political competition that drives governments, corporations, and individuals, has meant that there have been few-if any-constraining factors on human actions. This lack of constraint may be the biggest threat to human survival" [15].

\section{Context and Risks}

What is the state of the World today? How can we think in conserving species or restore ecosystems, with so many other problems? And why should we care for the other species?

To think sustainability and in ecosystems conservation implies managing a global peace, with international agreements, with action priorities and a profound knowledge of the causes.

The Millennium Development Goals (MDGs) developed by the United Na- 
tions (UN) enabled a first tier for the global peace, since "they have helped end poverty for some, but not all". The 8 MDGs (Table 1) worked, but they are still needed.

MDGs were improved by a new global agenda in 2015. Using them and the "six essential elements for delivering on the sustainable development goals", the UN proposed the 17 "Sustainable development Goals", SDGs (Figure 1), which are seen "as part of a new sustainable development agenda that must finish the job and leave no one behind".

(http://www.un.org/sustainabledevelopment/development-agenda/).

Why is having this global agenda so important? Because we are aware we need it! We are living the Sustainability time. Schools explain the concept, people/consumers are more aware and concerned towards environment changes and biodiversity loss, governments are applying measures and companies are focusing more on their sustainability reports following organizations like the "Global Reporting Initiative (GRI)" (https://www.globalreporting.org/Pages/default.aspx). But, having intentions and SDGs per se is not an insurance that everything will turn in favour.

Changes are happening that can compromise the work of those concerned with SDGs and sustainability: lack of tolerance between different cultures with arising conflicts, illnesses developed by toxic pollutants (more and more concentrated in nature), and diseases related to resistant pathogens.

The Ehrlich Equation (also known as IPAT Equation, where I = PAT, meaning "I" the impact on the environment or demand for resources; "P" the population size; " $\mathrm{A}$ " the affluence factor; and " $\mathrm{T}$ " the technology factor), predicts an increase in the value of the impact on environment, since population, affluence and technology are increasing [16].

The world is not blind to problems derived by human population. The Global Risks Report (GRR), is an example of that concern, being a "survey of the World Economic Forum's multi stakeholder communities", to know the perception of risks. A "global risk" is defined as "an uncertain event or condition that, if it occurs, can cause significant negative impact for several countries or industries

Table 1. Millennium development goals description (http://www.un.org/millenniumgoals/poverty.shtml).

\begin{tabular}{cc}
\hline Goal & Description \\
\hline 1 & Eradicate extreme poverty and hunger \\
2 & Achieve universal primary education \\
3 & Promote gender equality and empower women \\
4 & Reduce child mortality \\
5 & Improve maternal health \\
6 & Combat HIV/AIDS, malaria and other diseases \\
7 & Ensure environmental sustainability \\
8 & Develop a global partnership for development \\
\hline
\end{tabular}




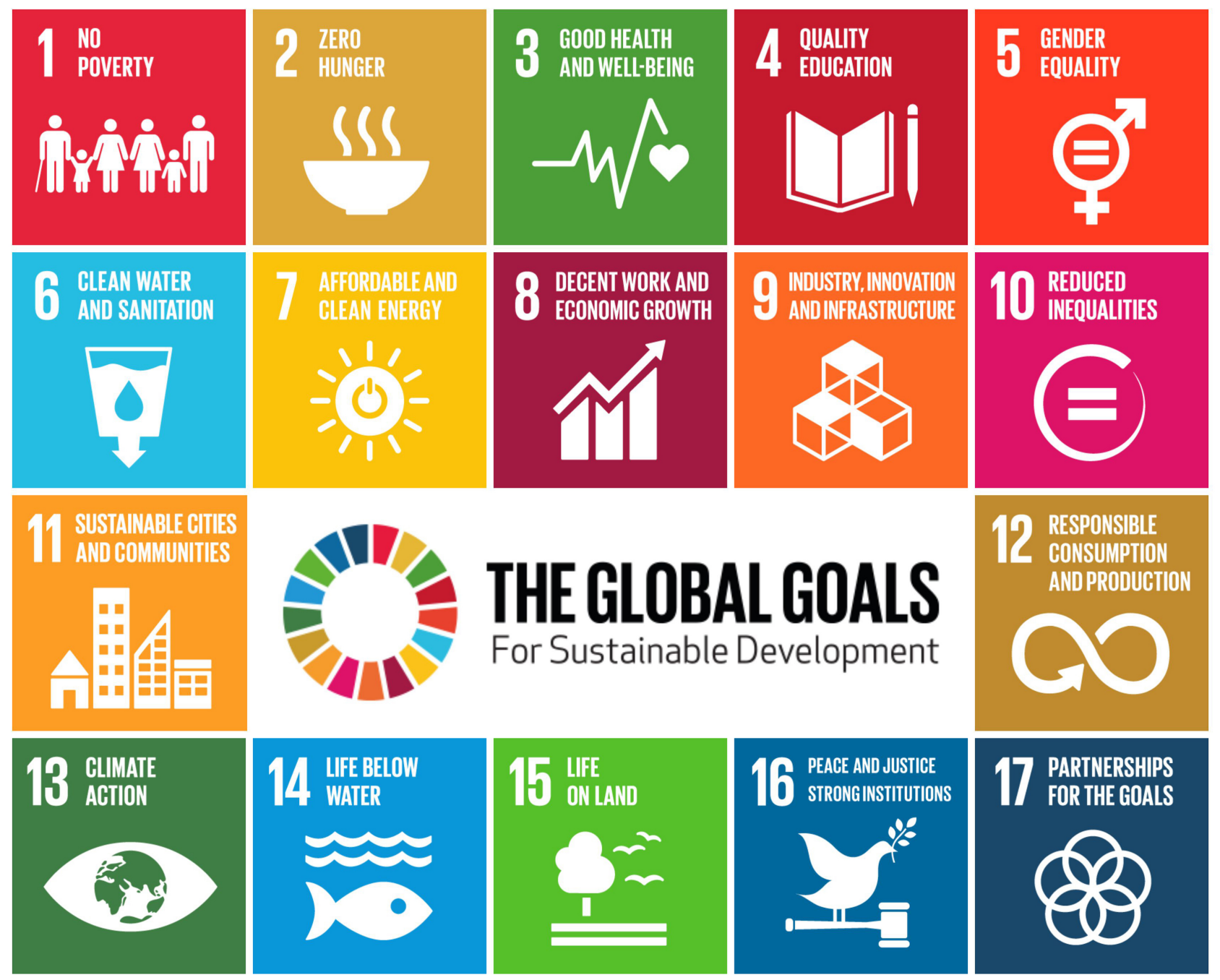

Figure 1. Sustainable development goals' icons, at https://sustainabledevelopment.un.org/post2015/transformingourworld.

within the next 10 years" [17]. Risks are categorized by "risks of highest concern", "risks of high impact and high likelihood" and "risks perceived to be most interconnected" [18]. In 2015 the "risks of highest concern (...) were fiscal crises in key economies, structurally high unemployment and underemployment, and the water crises", for example. Also, as "trends to watch" were the "decline of trust in institutions, lack of leadership, persisting gender inequalities and data mismanagement"; and experts added further concerns including "various forms of pollution, and accidents or abuse involving new technologies" [18].

One may ask: if stakeholders are aware of risks, why are governments resistant to adopt measures about climate change, and the loss of biodiversity?

Resistance to change is part of the human condition [19], and it would explain why climate negotiations are so difficult [15]. The report "Roads from Rio + 20, Pathways to achieve global sustainability goals by 2050" [20] shows the difficulties in managing politics to sustain "food, land and biodiversity" and "energy and climate". Authors appeal to an international consensus for developing better 
politics to manage these two spheres.

Many efforts have been taken, and many conferences and discussions have been prepared and attended by interested parties, and many reports emphasize similar preoccupations that one must ask: is it possible to achieve SDGs until 2050 ?

As some authors emphasize "strangely, we now find ourselves in an era of 'sustainable' marked by wildly proliferating claims of sustainability. Even as adjectives like 'low-carbon', 'climate-neutral', 'environmentally friendly', and 'green' abound, there is a remarkable absence of meaningful tests for whether particular governmental and corporate actions actually merit such descriptions" [15]. One must conclude that people don't need more "green" definitions... people need more effective action from all countries. And people need that measures and plans for "meaningful tests" happen with some urgency.

\section{The Demographic Problem and Its Consequences}

"People want decent jobs, social protection, robust agricultural systems and rural prosperity, sustainable cities, inclusive and sustainable industrialization, resilient infrastructure and sustainable energy for all" [6].

The ecological concept of carrying capacity can be applied, in theory, to our species. Each ecosystem/area has its limitations in what concerns the provision of resources to a certain population. For humans, these limits are more difficult to understand, since humans can modify their environment with their technological and scientific advances [21]. The concept of "carrying capacity" is very important for us, since it gives us a notion of limitation. When considering "limitations", projections based on the demographic and climate indicators are not in our favour. The IPCC [11] references that by 2020, between 75 - 250 million people in Africa will be subjected to water stress due to climate change, for example. It is our ingenuity to think that African countries problems are only Africa's problems. A place that offers so many problems to their people will lead them to migrate.

But how many are we? How many will we be? Human population is growing, and it is expected to reach 10.9 thousand million people by 2100 [22]. Projections show that the less developed countries will contribute with 69 per cent of the human growth, being 249 per cent from least developed countries by 2100 (when compared to data from 2010). Africa is the continent with more expression concerning this growth (Table 2).

The increase of human population expected for the period 2010-2100 is due to the global contributions of high fertility (13.8\%), declining mortality (16.3\%) and momentum of population growth (26.9\%) in Andreev et al. [22] perspective. The human population growth shows us that the World has been offering better health care, better nutrition, more basic material goods (Table 3 ) in many countries most likely, but it means also more pressures onto ecosystems. Many, probably, have already reached their carrying capacity. 
Table 2. Global population and population by continents, in 2010 and in 2100 (estimates), taken from the United Nations report, extracted from [22].

\begin{tabular}{ccccc}
\hline & \multicolumn{2}{c}{$\begin{array}{c}\text { Total Population } \\
\text { (Millions) }\end{array}$} & Population Change 2010-2100 \\
\hline Major Areas & 2010 & $\mathbf{2 1 0 0}$ & $\begin{array}{c}\text { Absolute } \\
\text { (Millions) }\end{array}$ & $\begin{array}{c}\text { Relative to } \\
\mathbf{2 0 1 0}(\%)\end{array}$ \\
\hline Global & 6916 & 10,854 & 3938 & 57 \\
Africa & 1031 & 4185 & 3153 & 306 \\
Asia & 4165 & 4712 & 546 & 13 \\
Europe & 740 & 639 & -101 & -14 \\
Latin America and Caribbean & 596 & 736 & 140 & 23 \\
North America & 347 & 513 & 167 & 48 \\
Oceania & 37 & 70 & 33 & 90 \\
\hline
\end{tabular}

Table 3. Human ill-being and well-being categories [1].

\begin{tabular}{cc}
\hline Ill-Being & Well-Being \\
\hline No freedom, powerless & Freedom of choice and action \\
Insecurity, conflict & Security \\
No health care, no health & Good health (physically, mentally, socially) \\
Poor social relations & Good social relations \\
No (or not enough) basic materials & Basic materials \\
\hline
\end{tabular}

\section{What Are the Consequences of This Demographic Growth?}

1) Less food (meat, vegetables). Several human activities were developed in order to provide humans the capacity for living longer in one place. Agriculture and fishing techniques nowadays, are a result of several millenniums of experimentation and knowledge gathering. The degree of knowledge we have may be sufficient to feed all global population. But why is it not? And what does that imply for humans and ecosystems?

When agriculture appeared, a technological way to manipulate vegetable species, there were about 5 million people on the Planet [23]. Now, we have much more people to feed. The problem is that in some of the poorest and most crowded places, where progress is little, there are low yields and low productivity in agriculture, which compromises food availability and security, and hinders the efforts to augment food security [24] [25].

Some authors emphasize that there is enough food to nurture global population needs [26]. However, poverty, precarious agriculture methods, and insufficient access to the markets by rural poor people undermine access to food [24]. In the FAO's indicators manual introduction (2014) one can read that "in spite of progress made over the last two decades estimated 840 million people still suffer from chronic hunger and two billion people worldwide are affected by micronutrient deficiencies" [27]. The "The Growing Problem" article [28] re- 
veals that the Far East and the Pacific, as well as the Sub-Saharan Africa, showed in 2009 the highest values of undernourishment of $63 \%$ and $26 \%$, respectively. Normally this leads people to destroy more habitats, jeopardizing their future (it's a vicious cycle).

Raven et al. [23] refer that the advances in agricultural technology will not be sufficient to provide all the goods for the needs of a growing population that will aggravate the pressures already seen and made on ecosystems. They conclude that "no matter how striking the advances of agricultural science might be, they will never be adequate to eliminate hunger in a world in which the population is growing rapidly".

Boy and Witt [29] emphasize that humans homogenized our crops, and in the $20^{\text {th }}$ Century people relied on approximately 20 crop plants to provide "more than $90 \%$ of our global vegetable intake", which scares when we think on the diversity of 6000 food crops our ancestries raised [29]. Of course, we can still count with genetic modified organisms, but this also comprises risks to the economy, especially to the small farmers, and to the natural world (since genomes are manipulated) [30].

2) Less Water available. Veldkamp et al. [31] use a global scale water scarcity assessment which takes in consideration the hydro-climatic variability but also the important temporal changes and the socioeconomic conditions. They found that from $17 \%$ (in 1960) to $45 \%$ (in 2000) of the total global population suffered of water shortage, and from $11.7 \%$ (1960) to $33.6 \%$ (2000) suffered of water stress. This means an increase in these two stressors. They also state that in that period, from $8.9 \%$ to $28.6 \%$ lived under both water shortage and stress conditions. This study demonstrates that the relative contribution of socio-economic change increased globally from $0 \%$ (in 1960) up to $76.2 \%$ (in 2000) for water shortage, and $82.5 \%$ for water stress, due to the continuous population growth that increased the water demand. In Africa, people suffer predominantly from water shortage. The study emphasizes the need for paying attention to climate variability as a key factor for designing strategies to cope with current water scarcity problems [31]. This data increases the drama of future scenarios.

3) Drastic fragmentation of habitats and more pressure on wild species. Fragmentation is increasing not only because humans occupy pristine land, or explore pristine areas of the ocean, but also because they modify abiotic parameters. The more vulnerable species are, the more pressured they feel in their environment if any parameter changes. Predictions show that rising water temperatures, changes in ice cover, salinity, oxygen levels and circulation with implications for marine and freshwater systems will happen [11]. Several studies indicate a decrease in ocean primary production [32]. This will limit the amount of available energy for higher trophic levels [33].

The rate of extinction is higher than it was expected [34] [35], and 20\% - 30\% of plant and animal species assessed by the IPCC (2007) are likely to be at increased risk of extinction if temperatures exceed $1.5^{\circ} \mathrm{C}-2.5^{\circ} \mathrm{C}$ in the near future. 
4) Pollution. Pollution is everywhere, since pollutants spread in the ecosystems. The poorer (subsistence farmers and artisanal fishermen) are already struggling against water scarcity and the lack of food, and they are not sufficiently resilient in scenarios of extreme weather events. Especially, because pressures on forests and marine ecosystems (perpetrated by the increase of the population, and by climate fluctuations) compromise food availability and security [33].

The demand for pesticides and fertilizers will increase, since more food supply is required [28]. This means an increase in pollution indices of the soil, aquifers, lakes, rivers and oceans. The pollutants will interfere with the quality of the services that ecosystems provide (provisioning, regulating and cultural services), therefore interfering with several species [11].

5) More and new diseases. An increase in fragmentation of ecosystems and an invasion of natural spots by communities is expected. This will lead to more encounters between wild species and humans, and more contact between wild species and humans and their livestock [15]. Emerging infectious diseases (EIDs) are to be expected due to these contacts [36]. As the rate of contact between humans, and their livestock and domesticated animals, and marine and land wildlife increases, the possibility of pathogens crossing land-sea and forest-rural area barriers also increases (Figure 2) [36].

6) More instability and dislocation of people. The "Roads to dignity by 2030 " [6] emphasizes that "we are a mobile world, with more than 232 million international migrants, and almost 1 billion when internal migrants are counted". People move in crises, because they need to find stability. By reducing the quality of life and well-being due to the ecosystems degradation, it is expected the migration of species (with disruption of habitats and niches) and people.

Governments must take measures to ensure that the elderly, women and children that are running from protracted crises, find a safe path to equilibrium. Many women and their children face migrations alone and because "women are not always able to claim family assets, such as land, livestock, tools and machinery, previously owned by their husbands, especially if they are illiterate or insufficiently aware of their legal rights" this has significant negative implications for food security [37].

\section{Tackling Demographic Growth Problems}

Governance needs to deal with demography issues. This means adopting plans
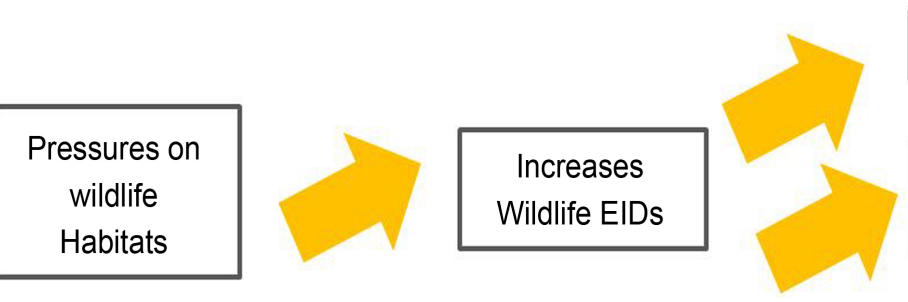

Accelerates species extinction

Increases zoonotic threat to human health

Figure 2. Chain of causes/effects that enable contacts between species and EID pathogens, adapted from [36]. 
to protect populations as well as the ecosystems. Each country has to study its territory and plan the distribution of people and protected areas.

In order to guarantee the well-being of people, increasing their incomes is not always a good measure (though monetary independence is needed) [16]. Access to family planning and to education is essential to empower people to decide about how to manage their lives (age of the first child; number of children per women) [22], and about the environment in a more altruistic manner [16]. Empowering women and future generations, providing them proper education conditions, is essential for a better, less poor world. This goal has to be taken as seriously as possible, especially because this "is the century of women", and one needs "to include the poor, children, adolescents, youth and the aged, as well as the unemployed, rural populations, slum dwellers, persons with disabilities, indigenous peoples, migrants, refugees and displaced persons, vulnerable groups and minorities" [6]. Globally, humankind needs to impose an "end to all forms of gender inequality, gender-based discrimination and violence against women and against children" [6] (UN, 2014).

Allowing oriented and controlled migration between countries is another measure. Countries desired by people must arrange protocols to help migrants, including climate migrants, escaping from protracted crisis. It is an important opportunity to empower women and children running from poverty, providing them security and education. It does not mean that these people, in a near future, can't go back to their original countries. It may function as a way to achieve some of the SDG goals. Migrations, nevertheless, have to be controlled because there are environmental and economical limitations in the receiving countries that must be respected. Some of the examples we have seen concerning climate migrants have implied aggravation of ecosystems degradation [15].

Exchanging skills between people of different countries may be taken more seriously, in a global manner. Countries with better education systems could have more exchange students from undeveloped countries. And more organizations like the Blue Ventures (http://blueventures.org/), and AGRA, may help to deal with the hunger problem. The Alliance for a Green Revolution in Africa (AGRA, http://www.agra.org/) develops programs for helping small-scale farmers and their families to design and apply solutions to increase their yields, minimizing negative impacts on ecosystems. It aims at gathering information about African soils, to improve their management, since there are so many poor and degraded soils and unreliable water supplies that when combined with poor access to markets, insufficient access to finance and credit and little government support, it jeopardizes the future of African people.

FAO [27] emphasizes the "family farming" solution that has the purpose of empowering subsistence farmers for better practices. This includes developing "individual innovation capacity through investment in education and training; also, incentives are needed for the creation of networks and linkages that enable different actors in the innovation system-farmers, researchers, advisory service 
providers, value chain participants, etc. - to share information and work towards common objectives" [27].

Improving agricultural yields using networking may be the best contribution of Science. A global agricultural monitoring network is needed

(https://www.earthobservations.org/cop_ag_gams_pp.shtml), since it enables monitoring the social, economic and environmental outcomes of agriculture, including food and nutrition security, human health, economic viability, social well-being and environmental sustainability [8].

Already in 2010, in an opinion article in Nature [7] authors argued about the importance of creating a method to compare between different agricultural methods, with quantifiable indicators (globally applicable metrics). The perspective was to be able to compare accurately different types of agricultural methods in order to plan strategies to improve the profitability of the more needy places [7]. They also emphasize that the network would help to create metrics for specific farming systems which would be of great importance to increase crop yields. This idea is compatible with FAO's [38] suggestion of concentrating efforts to improve family farming activities in developing countries.

In a review about the demographic growth in the Science Magazine, Godfray et al. [39] argue that, to cope with the feeding needs of 9 thousand million people, the world can focus in five tasks: close the yield gap, increase production limits, reduce waste, change diets, and expand aquaculture. Similarly, Foley [40] and the team of specialists with whom he worked, analysing agriculture effects in ecosystems (38.6\% or 50.2 million of $\mathrm{km}^{2}$ of terrestrial surface are used as pastures and cropping) propose, as well, five measures to solve the hunger problem: freeze agriculture's footprint, augment yields in already existent cropping lands, use water and technological resources more efficiently in every agricultural area, change diets to decrease protein demand, and reduce waste production.

All these authors [8] [39] [40] provide strategies to cope with the hunger problem. But, one ought to be aware that demographic growth must be better balanced in the future, and that measures between nations, like the measures quoted here, are certainly being taken.

\section{Tackling Climate Changes}

Hearing about climate change in the media is not new for us. We all heard the debate about how our way of living has compromised climate stability. But, for common observers, the debate may seem a little bit out of proportion. Why must people worry so importantly about our share in changing climate? Is it that important, arguing about if people are to blame, when Earth has historical episodes of climate instability?

Climate change "refers to a change in the state of the climate that can be identified (e.g. using statistical tests) by changes in the mean and/or the variability of its properties, and that persists for an extended period, typically decades or longer" [11] [41]. IPCC [11] [41] emphasizes that the term "climate change" re- 
fers to "any change in climate over time, whether due to natural variability or as a result of human activity".

Especially for Science, it is important to understand what the drivers of climate change are. It is important to understand what humanity's contribution to changes is. The debate of our participation on climate changes, was already surpassed by the scientific community, and, perhaps by the most informed part of society: "In its most recent assessment, IPCC states unequivocally that the consensus of scientific opinion is that Earth's climate is being affected by human activities", like the pollution of the atmosphere with greenhouse gases (GHGs) [42] [43]. Oreskes [42] [43] emphasizes that the "scientific consensus might, of course, be wrong", and continues saying that if "the history of science teaches anything, it is humility, and no one can be faulted for failing to act on what is not known". Accepting that we might have some guilt in Earth's last transformation, is the first step to mobilize efforts to deal with the problem. And this acceptance has to come from all parts of society (not just from scientific community or altruistic people).

The estimated impacts of the increase of temperature expected on weather, water, food, ecosystems, and society between 2030 and 2080 was explored in the WEF [44], which is shown in Figure 3.

Eastern Africa, for example, is expected to deal with several effects derived from climate change (Figure 4).

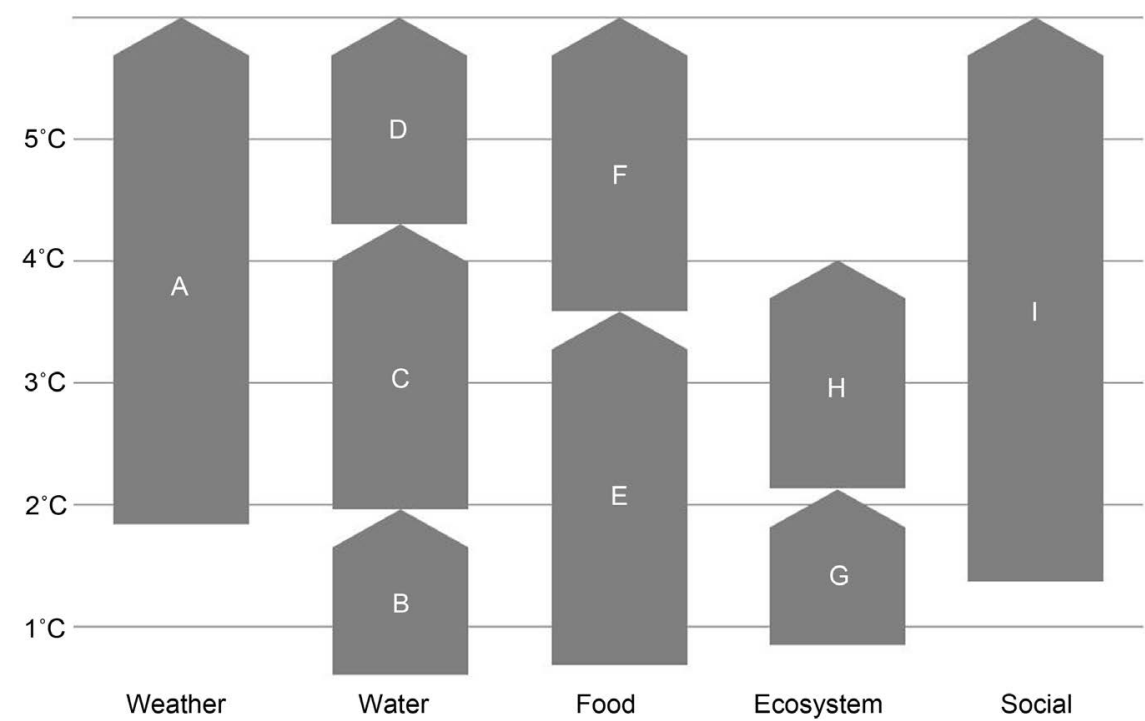

Figure 3. Possible impacts of global warming in different sectors (weather, water, food, ecosystems, society) between 2030 and 2080, according to average global temperature increase (Celsius degrees): A. Intense storms, forest fires, droughts, flooding and heat waves; B. Threat to local water supply as glaciers melt; C. Changes in water availability, threatening up to a billion people; D. Major cities around the world threatened by sea level rise; E. Falling crop yields in many developing regions; F. Falling yields in many developed regions; G. Ecosystems extensively and irreversibly damaged; H. Many more species face extinction; I. More than a billion people may have to migrate, increasing the risk of conflicts [44]. 


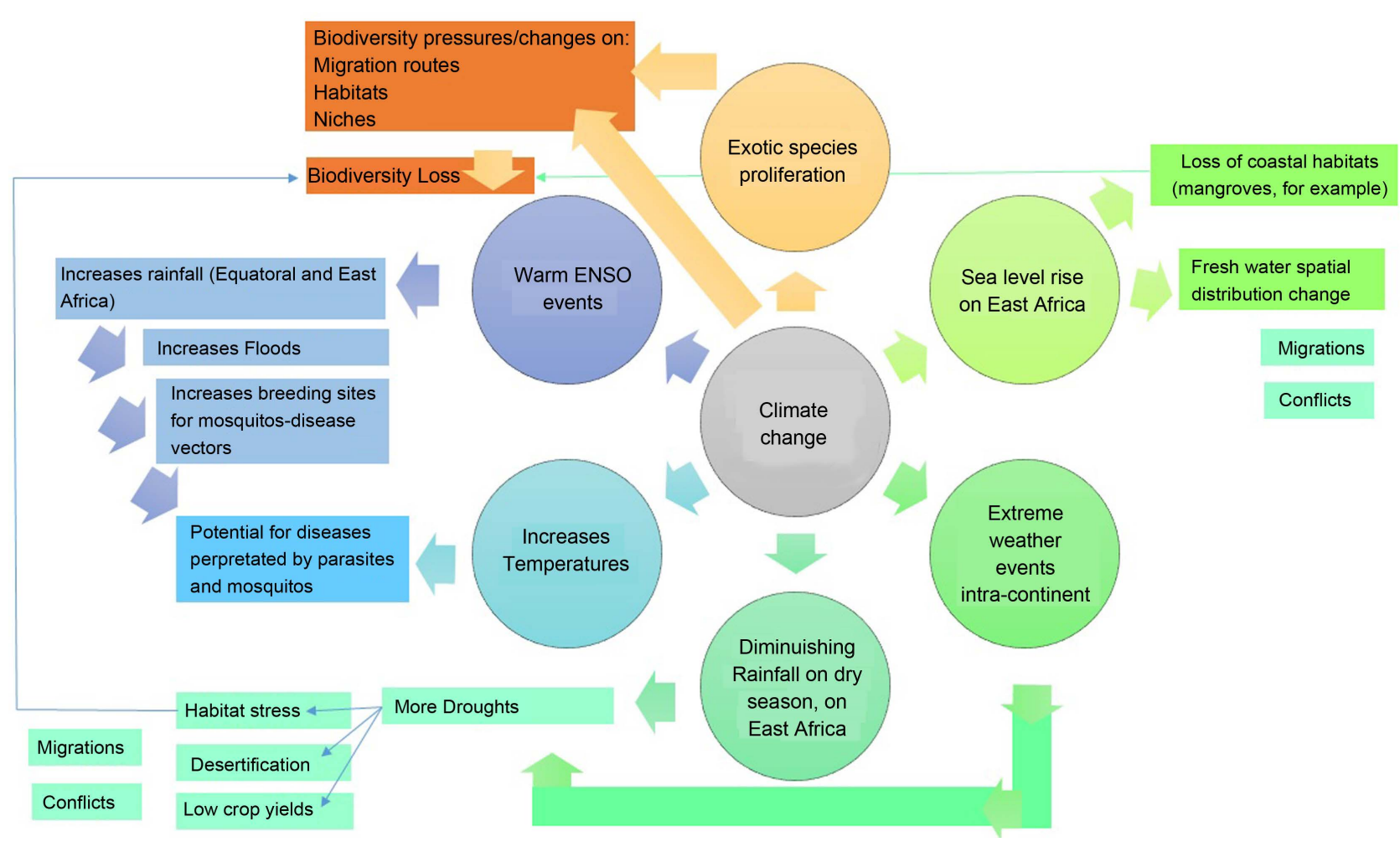

Figure 4. Climate change will augment effects like the proliferation of exotic species, sea level, temperatures, warm ENSO events, extreme intra-continent weather events, and diminish rainfall on dry season, adapted from [45].

Moreover, it is discussed if there is any need to mitigate the global temperature increasing, considering that the efforts are no longer sufficient to invert the patterns. Adaptation is advocated as the major strategy for the future generations (Figure 5). Many experts believe that it is important continuing to reduce GHGs emissions, by developing less fossil fuels-dependent societies [41]. IPCC [41] explores measures concerning adaptation, and strategies to build resilience (see pages 21 to 25 ).

\section{Tackling Biodiversity Loss}

Today the concept of sustainability [46] is used for many fields. It shows that efforts from entities like UN to advocate global goals (MDGs) have been successful in uniting several nations for biodiversity and ecosystems conservation, sharing the scientific prospects.

The Aichi Biodiversity Targets result from the engagement of the world to preserve the biodiversity. They were designed to be reached by 2020 (has a first stage) [47] [48] [49] [50] representing a full commitment to discontinue the loss of biodiversity. They are delivered as five strategic goals (Table 4), each defined by a group of targets (20 targets in total).

Some of the targets of the "Aichi Biodiversity Targets" [47] are a bit vague, opening views to different commitments and efforts by the different parties involved. This is not the opinion of Mace et al. [50] who consider the targets to be 


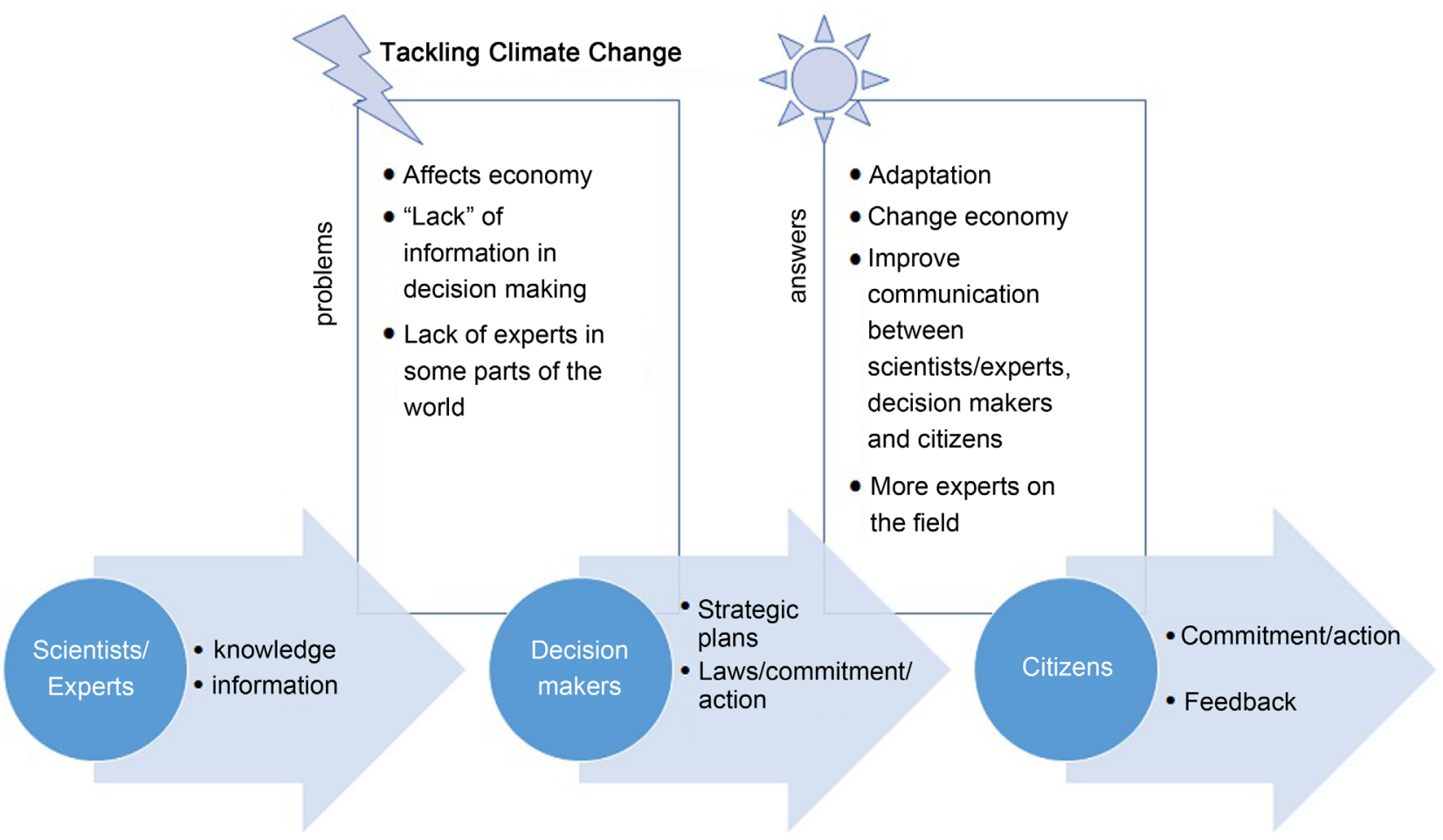

Figure 5. Summary of problems and measures to tackle climate changes.

Table 4. The five strategic Aichi biodiversity goals [47].

\begin{tabular}{|c|c|c|}
\hline & $\begin{array}{l}\text { Strategic } \\
\text { goal }\end{array}$ & Description of the SG \\
\hline 1 & SG A & $\begin{array}{c}\text { "Address the underlying causes of biodiversity loss by mainstreaming } \\
\text { biodiversity across government and society" }\end{array}$ \\
\hline 2 & SG B & $\begin{array}{l}\text { "Reduce the direct pressures on biodiversity } \\
\text { and promote sustainable use" }\end{array}$ \\
\hline 3 & SG C & $\begin{array}{l}\text { "Improve the status of biodiversity by safeguarding } \\
\text { ecosystems, species and genetic diversity" }\end{array}$ \\
\hline 4 & SG D & "Enhance the benefits to all from biodiversity and ecosystem services" \\
\hline 5 & SG E & $\begin{array}{c}\text { "Enhance implementation through participatory planning, knowledge } \\
\text { management and capacity building" }\end{array}$ \\
\hline
\end{tabular}

more specific and driving Parties for intended results, though they recognize the "biodiversity protection targets still lack baseline benchmarks and the kind of regular monitoring that would permit real tracking of trends".

Still, the majority of the current environmental targets intend to: increase generic capacities by setting priorities for assessments, plans or for the creation of stronger policies; minimize pressures on the environment, from the extraction processes to transformation or usage; reduce drivers that affect biodiversity loss; achieve specific states, \%, targets. The two last issues "are couched in very broad terms and often lack specific baselines and indicators" [50]. Also, for Mace et al., [50] targets need to be categorized, for which they propose categories by color 
(the red, blue and green targets classification).

Van Vuuren et al. [20] proposed clear short-term policy priorities, like: accelerate sustainable agricultural intensification (by creating proper conditions); reduce hunger (by improving a more robust food system); mainstream biodiversity considerations in land-use/water-use planning and management; and promote changes, such as in consumption patterns. Mace et al. [50] strongly emphasize that "parties need to adopt a small set of focused, relevant, efficient, and achievable targets", and they add that "these targets should have scientifically and socially appropriate outcomes and timescales, support biodiversity's role in human well-being, be linked to legislative and regulatory processes, be relevant at global scales but reflect local and national interests, and be open to accurate and efficient reporting". This last phrase is of capital importance. Taking this advice seriously is probably the only way to achieve the ambitious (but necessary) Convention on Biological Diversity's (CBD) mission to "take effective and urgent action to halt the loss of biodiversity in order to ensure that by 2020 ecosystems are resilient and continue to provide essential services, thereby securing the planet's variety of life, and contributing to human well-being, and poverty eradication" [48].

To be open to accurate and efficient reporting, parties must not only provide to supervisors information of their measures, but also, they must work an internal network of collaboration, as demonstrated in Figure 6.

In order to reduce species loss, Rands et al. [12] propose the "three interconnecting priorities" (Figure 6) which are managing biodiversity as a public good, integrating biodiversity into public and private decision-making, and creating enabling conditions for policy implementation. This demands full commitment

\begin{tabular}{|c|c|c|c|}
\hline $\begin{array}{l}\text { Policies/ } \\
\text { planning }\end{array}$ & $\begin{array}{c}\text { Research/ } \\
\text { Development of } \\
\text { New Technologies/ } \\
\text { Funding }\end{array}$ & $\begin{array}{l}\text { Communication/ } \\
\text { Education/ } \\
\text { Creating } \\
\text { awareness }\end{array}$ & Public Action \\
\hline & e three interconnect & ities (Rands et al., & \\
\hline $\begin{array}{l}\text { Governments } \\
\text { Politicians/ } \\
\text { Policy makers }\end{array}$ & $\begin{array}{l}\text { Economists/ } \\
\text { Universities, } \\
\text { Institutes/Labs/ } \\
\text { Academics/ } \\
\text { Researchers } \\
\text { Conservationists/ } \\
\text { Stakeholders/ } \\
\text { Enterprises }\end{array}$ & $\begin{array}{l}\text { Businesses/ } \\
\text { Schools } \\
\text { Teachers/ } \\
\text { Courts/ } \\
\text { Fire workers } \\
\text { Police/ } \\
\text { Media/... }\end{array}$ & Citizenship \\
\hline
\end{tabular}

Coals $2020 \Rightarrow 2050$

Aichii Goals and targets

Rio + 20 (see Figure 5.6.) SDGs

\section{Limit climate change}

Eradicate hunger (improve ecosystem yields)

Reduce water stress

Protect Biodiversity and Ecosystem Services

Reduce Waste

Use Red, Blue and Green targets

(Mace et al., 2010, 2013)

Figure 6. Vision about the global action needed to manage biodiversity, adapted from the SDGs and from views and ideas from several authors [12] [20] [39] [50]. 
from governments, which resides upon the collective choice of engaging with the CBD mission, putting it above economic interests and pressures.

In politics and in the economic sphere, ecosystems must be valued properly at a regional and landscape levels, by making room for more participation experts in conservation measures [51]. Jackson [16] goes further into the idea: "above all, the new macro-economy will need to be ecologically and socially literate, ending the folly of separating economy from society and environment". And this is urgent since "pressures on ecosystems will grow significantly worse during the first half of this century, unless human attitudes and actions change" [51].

\section{Conclusions}

Geology students know that Earth is a highly resilient system. Even when catastrophic pressures occurred, such as the impact of meteorites, the planet showed the plasticity of its ecosystems, which were reorganized, maintaining a life-friendly functionality. In this dynamic planet, species can evolve or extinguish. Our subspecies belongs to this rule. Due to its capacity and ingenuity, the Homo sapiens cannot control the changes of Nature. However, technology and science can develop strategies to cope with the exponential growth of species, including ours, the production of food, the spread of diseases, the exploitation of resources, and the degree of pollution.

Tackling many problems that concern humanity is driven by global projects and agendas. Leading these efforts are universities, governments, stakeholders, and common people that learned about ecosystems fragility. Being prepared to survive in the future depends on humanity's capacity to focus on achieving the SDGs. Global strategies have to be applied, supervised, publicized and taught to our future generations, because we are still learning how to manage ecosystems. Our goal is to use natural resources and services, damaging ecosystems as little as possible. Our goal is to stop being responsible for other species extinction. But, can we achieve these goals?

\section{References}

[1] MEA (Millennium Ecosystem Assessment) (2005) Ecosystems and Human Well-Being: Biodiversity Synthesis. World Resources Institute, Washington DC.

[2] Constanza, R., d'Arge, R., Groot, R., Farber, S., Grasso, M., Hannon, B., Limburg, K., Naeem, S., O’Neill, R.V., Paruelo, J., Raskin, R.G., Sutton, P. and van den Belt, M. (1997) The Value of the World's Ecosystem Services and Natural Capital. Nature, 387, 253-260. https://doi.org/10.1038/387253a0

[3] Díaz, S., Fargione, J., Chapin III, F.S. and Tilman, D. (2006) Biodiversity Loss Threatens Human Well-Being. PLoS Biology, 4, 1300-1305. https://doi.org/10.1371/journal.pbio.0040277

[4] Palmer, M.A. (2010) Water Resources: Beyond Infrastructures. Nature, 467, 534-535. https://doi.org/10.1038/467534a

[5] Molina, M.J. and Rowland, F.S. (1974) Stratospheric Sink for Chlorofluoromethanes: Chlorine Atom-Catalysed Destruction of Ozone. Nature, 249, 810-812. https://doi.org/10.1038/249810a0 
[6] UN (2014) The Road to Dignity by 2030: Ending Poverty, Transforming All Lives and Protecting the Planet. A/69/700, Synthesis Report of the Secretary-General on the Post-2015 Sustainable Development Agenda, UN, New York.

[7] Sachs, J., Remans, R., Smukler, S., Winowiecki, L. andelman, S.J., Cassman, K.G., Castle, D., DeFries, R., Denning, G., Fanzo, J., Jackson, L.E., Leemans, R., Lehmann, J., Milder, J.C., Naeem, S., Nziguheba, G., Palm, C.A., Pingali, P.L., Reganold, J.P., Richter, D.D., Scherr, S.J., Sircely, J., Sullivan, C., Tomich, T.P. and Sanchez, P.A. (2010) Monitoring the World's Agriculture. Nature, 466, 558-560. https://doi.org/10.1038/466558a

[8] Sachs, J.D., Remans, R., Smukler, S.M., Winowiecki, L. andelman, S.J., Cassman, K.G., Castle, D., DeFries, R., Denning, G., Fanzo, J., Jackson, L.E., Leemans, R., Lehmann, J., Milder, J.C., Naeem, S., Nziguheba, G., Palm, C.A., Pingali, P.L., Reganold, J.P., Richter, D.D., Scherr, S.J., Sircely, J., Sullivan, C., Tomichr, T.P. and Sancheza, P.A. (2012) Effective Monitoring of Agriculture: A Response. Journal of Environmental Monitoring, 14, 738-742.

[9] Scholes, R.J., Mace, G.M., Turner, W., Geller, G.N., Jürgens, N., Larigauderie, A., Muchoney, D., Walther, B.A. and Mooney, H.A. (2008) Toward a Global Biodiversity Observing System. Science, 321, 1044-1045. https://doi.org/10.1126/science.1162055

[10] Pereira, H.M., Ferrier, S., Walters, M., Geller, G.N., Jongman, R.H.G., Scholes, R.J., Bruford, M.W., Brummitt, N., Butchart, S.H.M., Cardoso, A.C., Coops, N.C., Dulloo, E., Faith, D.P., Freyhof, J., Gregory, R.D., Heip, C., Höft, R., Hurtt, G., Jetz, W., Karp, D.S., McGeoch, M.A., Obura, D., Onoda, Y., Pettorelli, N., Reyers, B., Sayre, R., Scharlemann, J.P.W., Stuart, S.N., Turak, E., Walpole, M. and Wegmann, M. (2013) Essential Biodiversity Variables. Science, 339, 277-278.

https://doi.org/10.1126/science.1229931

[11] IPCC (2007) Climate Change 2007: Synthesis Report. In: Core Writing Team, Pachauri, R.K. and Reisinger, A., Eds., Contribution of Working Groups I, II and III to the 4th Assessment Report of the Intergovernmental Panel on Climate Change, IPCC, Geneva, $73 \mathrm{p}$.

[12] Rands, M.R.W., Adams, W.M., Bennun, L., Butchart, S.H.M., Clements, A., Coomes, D., Entwistle, A., Hodge, I., Kapos, V., Scharlemann, J.P.W., Sutherland, W.J. and Vira, B. (2010) Biodiversity Conservation: Challenges beyond 2010. Science, 329, 1298-1303. https://doi.org/10.1126/science.1189138

[13] Paetzold, A., Warren, P.H. and Maltby, L. (2010) A Framework for Assessing Ecological Quality Based on Ecosystem Services. Ecosystem Services-Bridging Ecology, Economy and Social Sciences. Ecological Complexity, 7, 273-281. https://doi.org/10.1016/j.ecocom.2009.11.003

[14] De Groot, R.S., Alkemade, R., Braat, L., Hein, L. and Willemen, L. (2010) Challenges in Integrating the Concept of Ecosystem Services and Values in Landscape Planning, Management and Decision Making. Ecological Complexity, 7, 260-272. https://doi.org/10.1016/j.ecocom.2009.10.006

[15] SOTW (2015) State of the World 2015: Confronting Hidden Threats to Sustainability. Chapter 1, The Worldwatch Institute, Island Press. Washington DC.

[16] Jackson, T. (2011) Societal Transformations for a Sustainable Economy. Natural Resources Forum, 35, 155-164. https://doi.org/10.1111/j.1477-8947.2011.01395.x

[17] WEF (2016) The Global Risks Report 2016. 11th Edition, World Economic Forum within the Framework of the Global Competitiveness and Risks Team, World Economic Forum, Geneva, Ref: 080116. http://wef.ch/risks2016 
[18] WEF (2015) Global Risks 2015. 10th Edition, World Economic Forum within the Framework of the Global Competitiveness and Benchmarking Network, World Economic Forum, Geneva, Ref: 090115. http://reports.weforum.org/global-risks-2015/

[19] Watzlawick, P., Bavelas, J.B. and Jackson, D.D. (1967) Pragmatics of Human Communication, A Study of Interactional Patterns, Pathologies, and Paradoxes. WW Norton \& Company, New York.

[20] Van Vuuren, D., Kok, M., van der Esch, S., Jeuken, M., Lucas, P., Prins, A.G., Alkemade, R., van den Berg, M., Biermann, F., van der Grijp, N., Hilderink, H., Kram, T., Melamed, C., Pattberg, P., Scott, A., Stehfest, E., de Vries, B., te Velde, D.-W. and Wiggins, S. (2012) Roads from Rio+20. Pathways to Achieve Global Sustainability Goals by 2050. Summary and Main Findings to the Full Report, PBL Netherlands Environmental Assessment Agency, The Hague.

[21] Sadava, D., Hillis, D.M., Heller, H.C. and Berenbaum, M.R. (2011) Population Ecology. In: The Science of Biology, 9th Edition, Chapter 55, Sinauer Associates, Inc., Sunderland, 1167-1184.

[22] Andreev, K., Kantorová, V. and Bongaarts, J. (2013) Demographic Components of Future Population Growth. United Nations Department of Economic and Social Affairs, Population Division, Technical Paper No. 2013/3, United Nations, New York.

[23] Raven, P.H., Evert, R.F. and Eichhorn, S.E. (1992) Biology of Plants. 5th Edition, Section 6 Ecology and the Human Prospect, Chapter 31 Plants and People, Worth Publishers, New York, 686-711.

[24] Alexandratos, N. and Bruinsma, J. (2012) World Agriculture towards 2030/2050: The 2012 Revision. ESA Working Paper No. 12-03, Agricultural Development Economics Division, FAO, Rome.

[25] FAO, IFAD and WFP (2014) The State of Food Insecurity in the World 2014. Strengthening the Enabling Environment for Food Security and Nutrition. Food and Agriculture Organization of the United Nations, Rome.

[26] Holt-Gimenez, E. (2015) The Tragic Irony Is Having 70\% of the World's Farmers with Hungry. Interviewing Holt-Gimenez by Silva, A.R. in Público. https://www.publico.pt/

[27] FAO (2014) Acting on Food Insecurity and Malnutrition: Food Security Commitment and Capacity Profile. Methodology Paper, Food and Agriculture Organization of the United Nations, Rome.

[28] Nature (2010) Food: The Growing Problem. Nature, 466, 546-547.

[29] Boy, G. and Witt, A. (2013) Invasive Alien Plants and Their Management in Africa. Synthesis Report of the UNEP/GEF Removing Barriers to Invasive Plant Management in Africa (RBIPMA) Project, Implemented in Four African Countries (Ethiopia, Ghana, Uganda and Zambia) between 2005 and 2010, Gutenberg Press Limited, Malta.

[30] Wilson, E.O. (2004) Is Natural Selection Always the Engine of Evolution? In: Bindé, J., Ed., 21 st Century Debates. Where Are Values Going? UNESCO, 319-324.

[31] Veldkamp, T.I.E., Wada, Y., de Moel, H., Kummu, M., Eisner, S., Aerts, J.C.J.H. and Ward, P.J. (2015) Changing Mechanism of Global Water Scarcity Events: Impacts of Socioeconomic Changes and Inter-Annual Hydro-Climatic Variability. Global Environmental Change, 32, 18-29. https://doi.org/10.1016/j.gloenvcha.2015.02.011

[32] Boyce, D.G., Lewis, M.R. and Worm, B. (2010) Global Phytoplankton Decline over the Past Century. Nature, 466, 591-596. https://doi.org/10.1038/nature09268 
[33] Anastácio, R.S.S., Azeiteiro, U.M.M. and Pereira, M.J.V. (2012) Climatic Changes, Nutrient Imbalance and Primary Productivity in Aquatic Ecosystems. Tropical Oceanography, 40, 1-16. https://doi.org/10.5914/tropocean.v40i1.5189

[34] Ceballos, G., Ehrlich, P.R., Barnosky, A.D., García, A., Pringle, R.M. and Palmer, T.M. (2015) Accelerated Modern Human-Induced Species Losses: Entering the Sixth Mass Extinction. Science Advanced, 1, e1400253. https://doi.org/10.1126/sciadv.1400253

[35] Ceballos, G., Ehrlich, P.R. and Dirzo, R. (2017) Biological Annihilation via the Ongoing Sixth Mass Extinction Signaled by Vertebrate Population Losses and Declines. PNAS, 114, E6089-E6096. http://www.pnas.org/cgi/doi/10.1073/pnas.1704949114

[36] Daszak, P., Cunningham, A.A. and Hyatt, A.D. (2001) Anthropogenic Environmental Change and the Emergence of Infectious Diseases in Wildlife. Acta Tropica, 78, 102-116.

[37] FAO, IFAD and WFP (2015) The State of Food Insecurity in the World 2015. In: Meeting the 2015 International Hunger Targets. Taking Stock of Uneven Progress, Food and Agriculture Organization of the United Nations, Rome, 56 p.

[38] FAO (2014) The State of Food and Agriculture: Innovation in Family Farming. Food and Agriculture Organization of the United Nations, Rome.

[39] Godfray, H.C.J., Beddington, J.R., Crute, I.R., Haddad, L., Lawrence, D., Muir, J.F., Pretty, J., Robinson, S., Thomas, S.M. and Toulmin, C. (2010) Food Security: The Challenge of Feeding 9 Billion People. Science, 327, 812-818. https://doi.org/10.1126/science.1185383

[40] Foley, J. (2014) How to Feed 9 Billion. National Geographic, 14, 2-29. (In Portuguese) https://pt.slideshare.net/pacadifam/national-geographic-portugalmaio2014

[41] IPCC (2014) Summary for Policymakers. In: Field, C.B., Barros, V.R., Dokken, D.J., Mach, K.J., Mastrandrea, M.D.,Bilir, T.E., Chatterjee, M., Ebi, K.L., Estrada, Y.O., Genova, R.C., Girma, B., Kissel, E.S., Levy, A.N., MacCracken,S., Mastrandrea, P.R. and White, L.L., Eds., Climate Change 2014: Impacts, Adaptation, and Vulnerability, Part A: Global and Sectoral Aspects, Contribution of Working Group II to the Fifth Assessment Report of the Intergovernmental Panel on Climate Change, Cambridge University Press, Cambridge, New York, 1-32.

[42] Oreskes, N. (2004) The Scientific Consensus on Climate Change. Essay beyond the Ivory Tower. Science, 306, 1686. https://doi.org/10.1126/science.1103618

[43] Oreskes, N. (2005). The Scientific Consensus on Climate Change (Erratum). Science, 307, 355 .

[44] WEF (2013) Global Risks 2013. 8th Edition, An Initiative of the Risk Response Network, World Economic Forum 2013, Ref: 301211.

[45] Case, M. (2006) Climate Change Impacts on East Africa: A Review of the Scientific Literature. WWF-World Wide Fund for Nature (Formerly World Wildlife Fund), Gland. http://agris.fao.org/agris-search/search.do?recordID=GB2013202275

[46] Brundtland, H. (1987) Our Common Future, From One Earth to One World. An Overview by the World Commission on Environment and Development, Report of the WCED, Experts Group on Environmental Law, Oslo.

[47] CBD/UNEP (2010) Strategic Plan for Biodiversity 2011-2020 and the Aichi Biodiversity Targets-Brochure. 2010 CBD/UNEP. https://www.cbd.int/sp/

[48] UNEP, CBD and COP (2010) The Strategic Plan for Biodiversity 2011-2020 and the Aichi Biodiversity Targets: Living in Harmony with Nature. UNEP/CBD/COP/DEC/X/2. Decision Adopted by the Conference of the Parties to the Convention on Biological 
Diversity at Its Tenth Meeting, Nagoya.

[49] UNEP, CBD, and COP (n/d) United Nations Decade on Biodiversity 2011-2020. Excerpt from COP Decision XI/2 (UNEP/CBD/COP/DEC/XI/2) Strategy for the Celebration of the United Nations Decade on Biodiversity 2011-2020.

[50] Mace, G.M., Perrings, C., Le Prestre, P., Cramer, W., Díaz, S., Larigauderie, A., Scholes, R.J. and Mooney, H.A. (2013) Science to Policy Linkages for the Post-2010 Biodiversity Targets. In: Collen, B., Pettorelli, N., Baillie, J.E.M. and Durant, S.M., Eds., Biodiversity Monitoring and Conservation: Bridging the Gap between Global Commitment and Local Action, John Wiley \& Sons, Ltd., New York, 291-310. https://doi.org/10.1002/9781118490747.ch13

[51] MEA (Millennium Ecosystem Assessment) (2007) A Toolkit for Understanding and Action, Protecting Nature's Services. Protecting Ourselves. Island Press, Washington DC.

\section{Acronyms}

AGRA-Alliance for a Green Revolution in Africa;

CBD-Convention on Biological Diversity;

CFC-Chlorofluorocarbon;

EBV_-Essential Biodiversity Variables;

EID_Emerging Infectious Diseases;

ENSO-El Niño-Southern Oscillation;

EPS-Ecosystem Services Profile;

HIV/AIDS-Human Immunodeficiency Virus Infection/Acquired Immune Deficiency Syndrome;

FAO_Food and Agriculture Organization of the United Nations;

GCOS-Global Climate Observing System;

GCOS/WMO_Global Climate Observing System/World Meteorological Organization;

GEOBON-Group on Earth Observations Biodiversity Observation Network;

GHG-GreenHouse Gases;

GRI-Global Reporting Initiative;

GRR_Global Risks Report;

GRR/WEF_-Global Risks Report/World Economic Forum;

IPCC-Intergovernmental Panel on Climate Change;

MDG-Millennium Development Goals;

MEA-Millennium Ecosystem Assessment;

SDG-Sustainable Development Goals;

SOTW-State of the World;

SPB-Strategic Plan for Biodiversity;

UN-United Nations;

UNEP/CBD/COP_United Nations Environment Programme/Convention on Biological Diversity/Conference of the Parties. 